\title{
THE PHOTOVOLTAIC INSTALLATION APPLICATION IN THE PUBLIC UTILITY BUILDING
}

\author{
ZASTOSOWANIE INSTALACJI FOTOWOLTAICZNEJ \\ W BUDYNKU UŻYTECZNOŚCI PUBLICZNEJ
}

\begin{abstract}
The article presents the use of photovoltaic installation in a building with office space and a section for kindergarten to support the production of electricity using solar energy. Accepted technological installation solution, capital expenditures to be incurred for the project and payback time are shown. Paper presents the results of the performance simulation of the PV system adopted depending on the angle of photovoltaic panels. Designed photovoltaic installation consists of 62 panels with a total nominal power of $15.5 \mathrm{~kW}$. The use of photovoltaics in the facility allow reducing carbon dioxide emissions into the atmosphere by approximately $52 \%$. In Poland, most of the electricity produced is still based on coal and lignite. Photovoltaics is one of the renewable sources of energy, so-called "Green" energy. The investment could be made thanks to the Regional Operational Programme Podlaski, Activity 5.2 Development of local infrastructure, environmental protection 2007-2013.
\end{abstract}

Keywords: renewable energy sources, solar radiation, PV plant

\section{Introduction}

The use of energy systems gaining electricity or thermal energy from renewable energy sources (RES) can give us energy independence, and thus reduce operating costs for heating, hot water heating, and lighting in the building [1-4], and additionally it can provide reduction of harmful compounds emission into the environment, such as $\mathrm{CO}_{2}, \mathrm{NO}_{\mathrm{x}}, \mathrm{SO}_{\mathrm{x}}$ or heavy metals.

The European Union in its activities strongly supports and promotes RES development. EU legislation on RES support has issued a number of projects and directives. The most important one is Directive 2009/28/EC (April 23, 2009) on the use of energy from RES (e.g. sun, water, wind, biomass). Poland is obliged under this directive to obtain a minimum $15 \%$ share of RES energy production by $2020[5,6]$.

Solar energy among all types of energy sources is characterized by unlimited resources, easy accessibility, the least negative impact on the natural environment. The difficulty in obtaining solar energy resulting from diurnal and seasonal variability is its main disadvantage [7-10]. In Poland, the most intensive intensity of solar radiation falls on

\footnotetext{
${ }^{1}$ Department of Heating, Ventilation, Air Conditioning, Faculty of Civil Engineering and Environmental Engineering, Bialystok University of Technology, ul. Wiejska 45E, 15-351 Bialystok, Poland, phone +48 8574696 35, fax +48 8574695 76, email: j.piotrowska@pb.edu.pl
} 
the spring - summer period. The solution could be the accumulation of solar energy, unfortunately there is still no cheap and effective way of storage.

The use of photovoltaic installation seems to be a prospective and fast-growing technology that makes it possible to obtain energy from RES to cover the part of the small dispersed facilities needs [11-13]. The interest in the application of RES in buildings results from the possibility of relieving the existing power grids and reducing the costs associated with their operation.

The paper presents a completed investment in which a new photovoltaic installation with a nominal power of $15.5 \mathrm{kWp}$ was made to secure the electrical needs of the office building. Adopted technological solutions, cost of solar installation, payback time and savings as a result of its application were shown.

\section{Location and description of the building}

The building is located in Bialystok, in the western part of the macro-region of Bialystok Upland, lying in the north - eastern part of the Poland. Location of the object is define by the geographic coordinates: latitude $53^{\circ} 7^{\prime} 45^{\prime \prime} \mathrm{N}$ and longitude $23^{\circ} 7^{\prime} 9^{\prime \prime} \mathrm{E}$. The climate of Bialystok is quite raw with the clear influence of continental climate, which is characterized by harsh winters and hot and dry summers. Characteristic for the city climatological conditions are as follows: the average annual temperature is $6.9^{\circ} \mathrm{C}$; the number of heating days is 232 ; average daily humidity is $88 \%$; the average insolation is 1,720 hours; average cloudy 5.3 octanes ( 0 octane - no clouds, 8 octane - total cloud cover). This area is dominated by westerly winds, with a deviation south to north with an average speed of $2.5 \mathrm{~m} / \mathrm{s}$. The number of frosty days is 50-60, with $110-138$ frost days, snow cover period of 90-110 days.

It is a detached building (Fig. 1), made with traditional, built in 2003. The total area of the building is $758.91 \mathrm{~m}^{2}$ and $2,078 \mathrm{~m}^{3}$ volume. At the offices is intended II and III floor of the building, and the whole ground floor is occupied by a kindergarten.

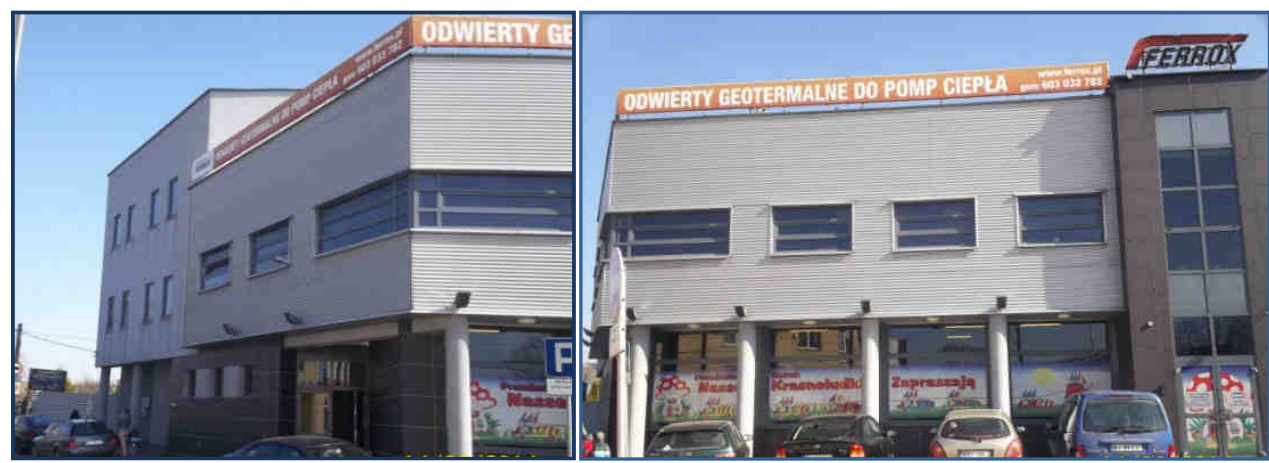

Fig. 1. A view of the described building [photo: author]

The dimensions of the available roof area, on which the photovoltaic installation can be mount, are $18 \mathrm{~m} \times 25 \mathrm{~m}$, but it is limited by various structures installed on the roof, i.e. ventilation chimneys, walls of fire, the existing two vacuum solar collectors (Fig. 2), hence actually available area is $372 \mathrm{~m}^{2}$. All of these elements are unfortunately a source of 
local shading. Another element hampering installation of photovoltaic panels is heterogeneous roof structure of the building, added in the north - eastern part of the roof of the third floor (Fig. 3), so the roof has two levels.

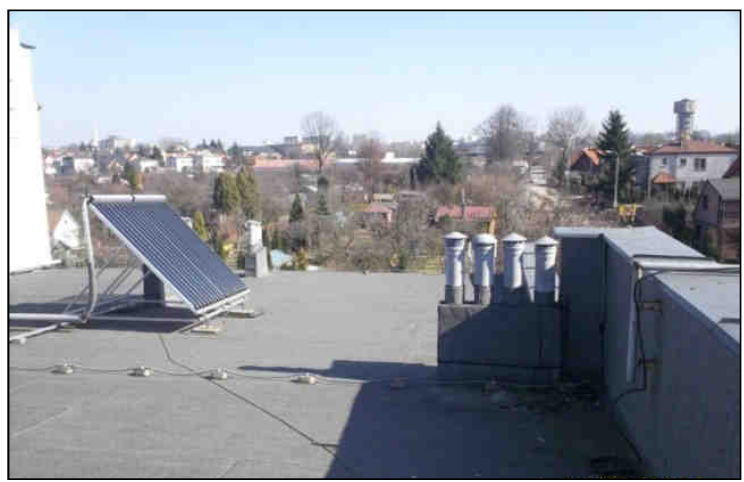

Fig. 2. Rooftop view of the elements of shading: ventilation chimneys, fire wall and system of solar collectors (for removal) [photo: author]

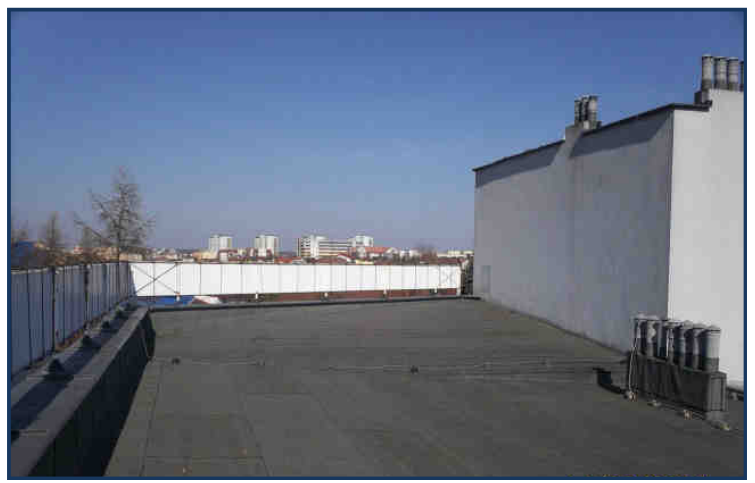

Fig. 3. Rooftop view with a fragment of the fire wall and protruding third floor annex building construction [photo: author]

Mounted third floor (Fig. 3), is unfortunately an obstacle to the installation of photovoltaic panels in the lower north - western part of the roof because of its shading.

Computational thermal power for heating purposes is $38.9 \mathrm{~kW}$, thermal power heating system for domestic hot water is $6.3 \mathrm{~kW}$. Annual energy consumption for the building heating is $385.4 \mathrm{GJ}$.

Electricity is consumed in the building for lighting, DHW (Domestic Hot Water) heating, office equipment like fax machines, printers, computers, shredders, etc., air conditioners and devices included in the server room, as well as automatic control unit and circulation pump in the boiler room. Annual consumption of electricity in the building is $24174 \mathrm{kWh} /$ year.

As part of comprehensive modernization of the energy system of the building was made the concept of the use of renewable energy sources (RES), business plan and acquired 
funds from the Regional Operational Programme Podlaskie, Activity 5.2 - Development of local environmental protection infrastructure.

In the realized investment was made a new photovoltaic installation with a nominal power of $15.5 \mathrm{~kW}$, was installed high-efficiency solar collectors with a total area of $5.619 \mathrm{~m}^{2}$ absorber, and to protect the heating needs of the building was installed heat pump type brine/water heat output $38 \mathrm{~kW}$ with vertical geothermal probes for the total length of $800 \mathrm{~m}$.

The paper presents the use of photovoltaic installation in a building of mixed-use functions: office - kindergarten to support the production of electricity using solar energy. Accepted technological solution installation cost of the investment and savings resulting from the application were shown. The results of a simulation of the PV system performance according to different angles of photovoltaic panels exposed in a southerly direction were presented.

\section{Description of the photovoltaic installation technology}

The photovoltaic system consists of 62 photovoltaic panels $250 \mathrm{~W}$ power each mounted on the roof of the building.

The total designed installation power is $15.5 \mathrm{~kW}$. Photovoltaic panels are divided into three sections. The first and second section located on the lower part of the roof consists of 23 panels modules, $5.75 \mathrm{~kW}$ power and a third section located on the upper part of the roof consists of 16 panels modules, $4 \mathrm{~kW}$ power. Figures 4 and 5 show the positioning of the three sections of photovoltaic panels in the most efficient way to eliminate shading zones on the roof.

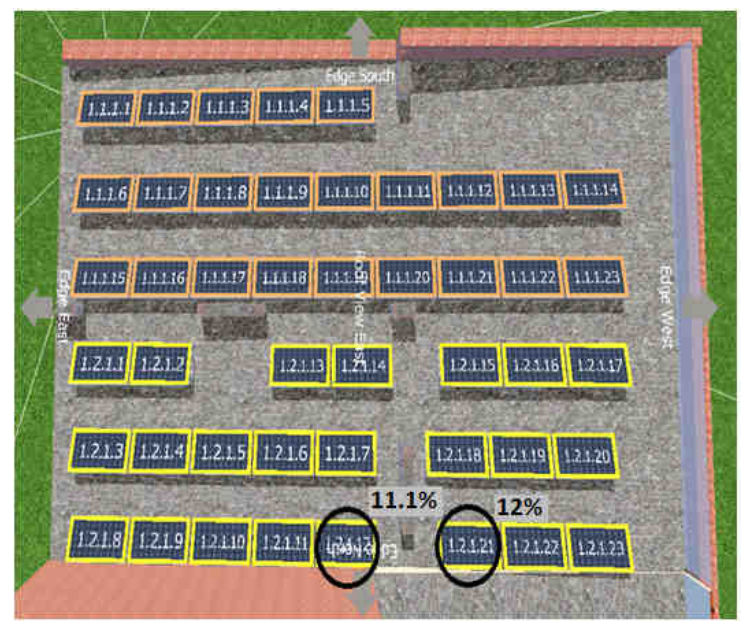

Fig. 4. Deployment of photovoltaic panels, Section 1 (orange) and Section 2 (yellow) 23 modules each on the lower part of the roof [14]

With the setting of photovoltaic panels according to Figure 4 degree of shading modules in Section 1 and Section 2 ranges from 0.9 to $12 \%$ per year. Two photovoltaic 
panels in Section 2 indicated as "1.2.1.12" and "1.2.1.21" had a degree of shading ratio 11.1 and $12 \%$. So it was necessary to change the location of these two panels.

In Section 3, as shown in Figure 5 the degree of shading in the year is from 0.5 to $4.1 \%$, therefore setting the solar panels is optimal.

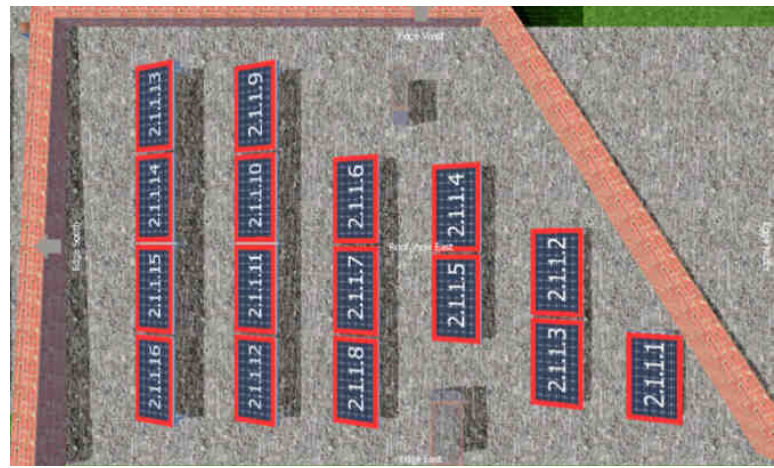

Fig. 5. Deployment of photovoltaic panels, Section 3 (red) 16 modules on the upper part of the roof [14]

Shading of photovoltaic panels exceeding $10 \%$ reduces the efficiency of the cell, shaded modules are exposed to the risk of so-called hot spots which after a few years of use can permanently damage the shaded field. The efficiency of these photovoltaic panels is further reduced [15].

When installing photovoltaic panels horizontal with $25^{\circ}$ the minimum distance between adjacent rows of photovoltaic panels is determined based on consideration of the shortest day of the year and on the angle of the sun which then occurs, should be $1.87 \mathrm{~m}$.

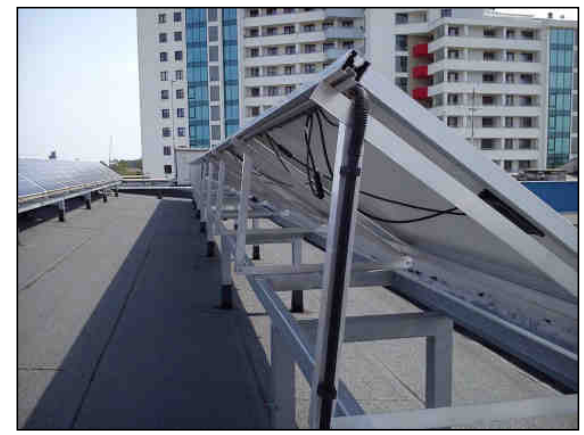

Fig. 6. An exemplary proposed method of photovoltaic panels installation on a supporting structure, for example, the Electrical Technical School building in Bialystok [photo: author]

The total gross floor area of photovoltaic panels installed is $101.38 \mathrm{~m}^{2}$. The dimensions of a single photovoltaic panel are $983 \mathrm{~mm} \times 1670 \mathrm{~mm}$, efficiency specified by the manufacturer $15.3 \%$, resistance to static loads (wind, snow, ice), approximately $800 \mathrm{~kg} / \mathrm{m}^{2}$.

Photovoltaic panels on the roof were installed using ballast design, used in the earlier analysis anchored assembly to the roof structure shown in Figure 6, excluded due to the 
design of the roof and its insulation $20 \mathrm{~cm}$ layer of insulation with two layers of tar paper finish.

Initially, photovoltaic panels were to be installed at an angle of $25^{\circ}$, but due to exceeding the permissible roof loads by load of ballast, the angle of the panels to the horizontal plane is reduced. Additionally, the safe roof area have been calculated for example for snow load by means of a specially manufactured for this purpose snow layer thickness indicator. Exceeding the maximum level marked on the dipstick may result the damage of the roof structure. Snow layer thickness indicator and angle of the photovoltaic panels on the roof are shown in Figure 7.

In the winter, photovoltaic panels must be cleaned of residual layer of snow on them, because the angle at which photovoltaic panels are mounted on the roof, does not provide a complete snow slide.

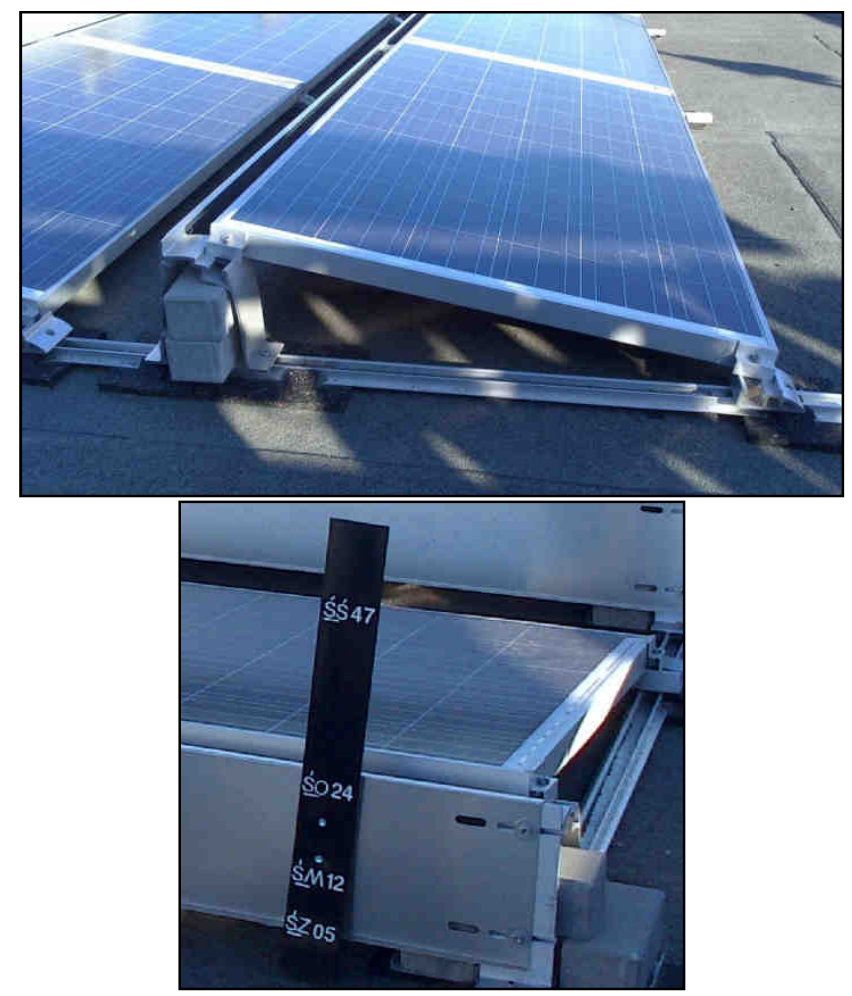

Fig. 7. The setting angle of the photovoltaic panels on the roof of the Ferrox company and safe snow cover indicator [photo: author]

Photovoltaic panels were connected with dedicated DC wires to circuit systems that are connected to the inverter, in which electrical energy is converted to a voltage with a frequency of $50 \mathrm{~Hz}$ and further transferred to AC power switchgear. Where is localized measurement of the energy produced gross and additional security system. View switchgear with control and measuring system is shown in Figure 8. 


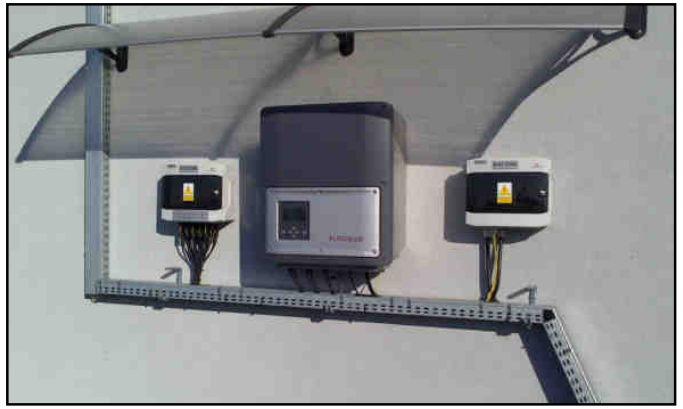

Fig. 8. View of the switchgear and the control - measurement system [photo: author]

Used in the photovoltaic installation inverters in automatic mode, adjust the parameters of the produced electricity to the network parameters and ensure safe operation by preventing them from working insular. The inverters are equipped with an internal monitoring system, which allows monitoring of the entire photovoltaic system. Inverters have up to three independent DC inputs each, with a separate controller. These controllers allow to optimize the work of a team of PV modules by reducing the influence of local shades [16]. They were made three independently operating sections of photovoltaic panels, a failure or a jam one of the section does not affect the other.

Working photovoltaic Section 1 and Section 2 mounted on the lower part of the roof are shown in Figure 9 and Section 3 mounted on the upper part of the roof is shown in Figure 10.

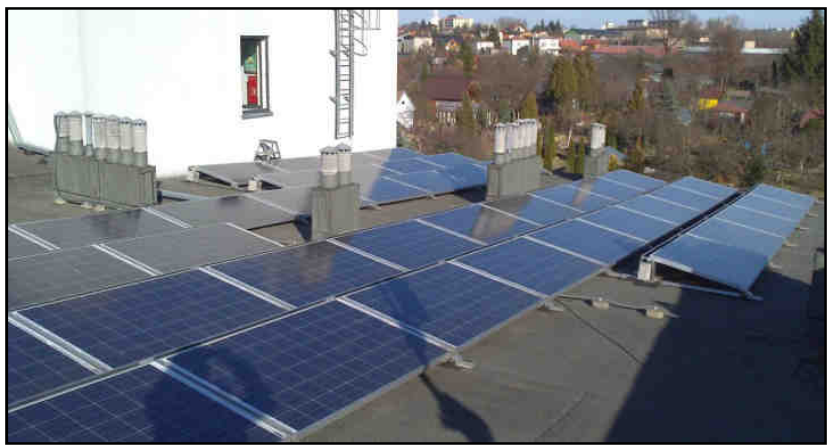

Fig. 9. View of the photovoltaic panels mounted at an angle of $15^{\circ}$, Section 1 and Section 2 , on the lower part of the roof [photo: author]

Changing the angle of the solar panels from $25^{\circ}$ to $15^{\circ}$ will affect the installation yields in the autumn and winter and early - spring, in the months from October to March.

Important elements of the photovoltaic installation affecting their operation and performance is to ensure optimal ventilation to the back of photovoltaic panels, allowing a reduction in temperature, and thus obtain a higher efficiency. Also important is maintaining the cleanliness of the surface of photovoltaic panels, where in case of surface contamination is reduced both their performance as well as efficiency. A large impact on reliability has also the aging process of cells. 


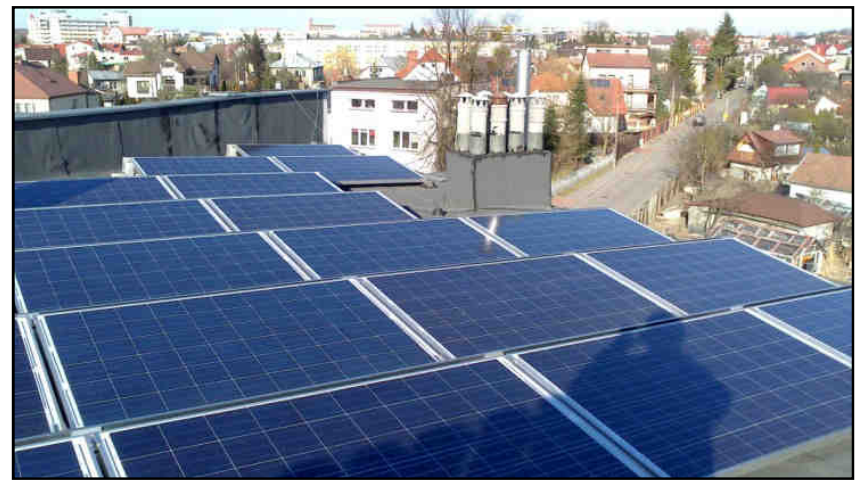

Fig. 10. View of the photovoltaic panels mounted at an angle of $15^{\circ}$, Section 3, on the upper part of the roof [photo: author]

The photovoltaic system is working in parallel with the electricity network without putting energy into it. Photovoltaic cells are now working only for the internal network. For a period of five years after the end of the program the company cannot sell surplus electricity to the grid. In the event of a surplus of electricity its flow is currently blocked.

\section{Technical-economic analysis}

The total power of all installed electrical equipment in the building is approximately $16 \mathrm{~kW}$, including the power to cover only the needs of the lighting is $3 \mathrm{~kW}$. Connected load of the building is $31 \mathrm{~kW}$.

Based on the electricity bill the value of annual electricity consumption in the building was estimated and it amounts to $24,174 \mathrm{kWh} / \mathrm{year}$. The annual costs of purchasing electricity in the tariff $\mathrm{C} 11$ before the PV system installation is about 19,082 PLN $(4,786.3 €)$.

Monthly consumption of electricity, together with the costs incurred by the investor on the basis of invoices per Euro, is shown in Figure 11.

To cover the total power of all equipment, the system consisting of 62 photovoltaic modules with $250 \mathrm{~W}$ nominal power each, mounted at an angle of $15^{\circ}$, with two inverters was selected. The total designed output of the installation is $15.5 \mathrm{kWp}$. The installation is divided into three sections respectively $5.75 \mathrm{~kW}$ (23 PV-modules) in Sections 1 and 2 and $4 \mathrm{~kW}$ (16 PV-modules) in Section 3. The gross area of photovoltaic panels is $101.35 \mathrm{~m}^{2}$.

In Table 1 are listed the total expenditures to be incurred for the construction of photovoltaic installations with $15.5 \mathrm{kWp}$ power. The costs include equipment with control and supervisory systems together with installation, commissioning and installation of software systems supervising the work of the entire system.

Total investment costs of purchase and the photovoltaic system installation in the building, without the use of subsidies, will be about 116,850 PLN (29,309€).

Using the subsidies, e.g. within the framework of the Regional Operational Programme Podlaski, Activity 5.2. Development of local environmental protection infrastructure can be count on financing investment of $65 \%$, hence the total investment costs of purchase and the photovoltaic system installation in the building will amount to approximately 40,898 PLN $(10,258 €)$. 


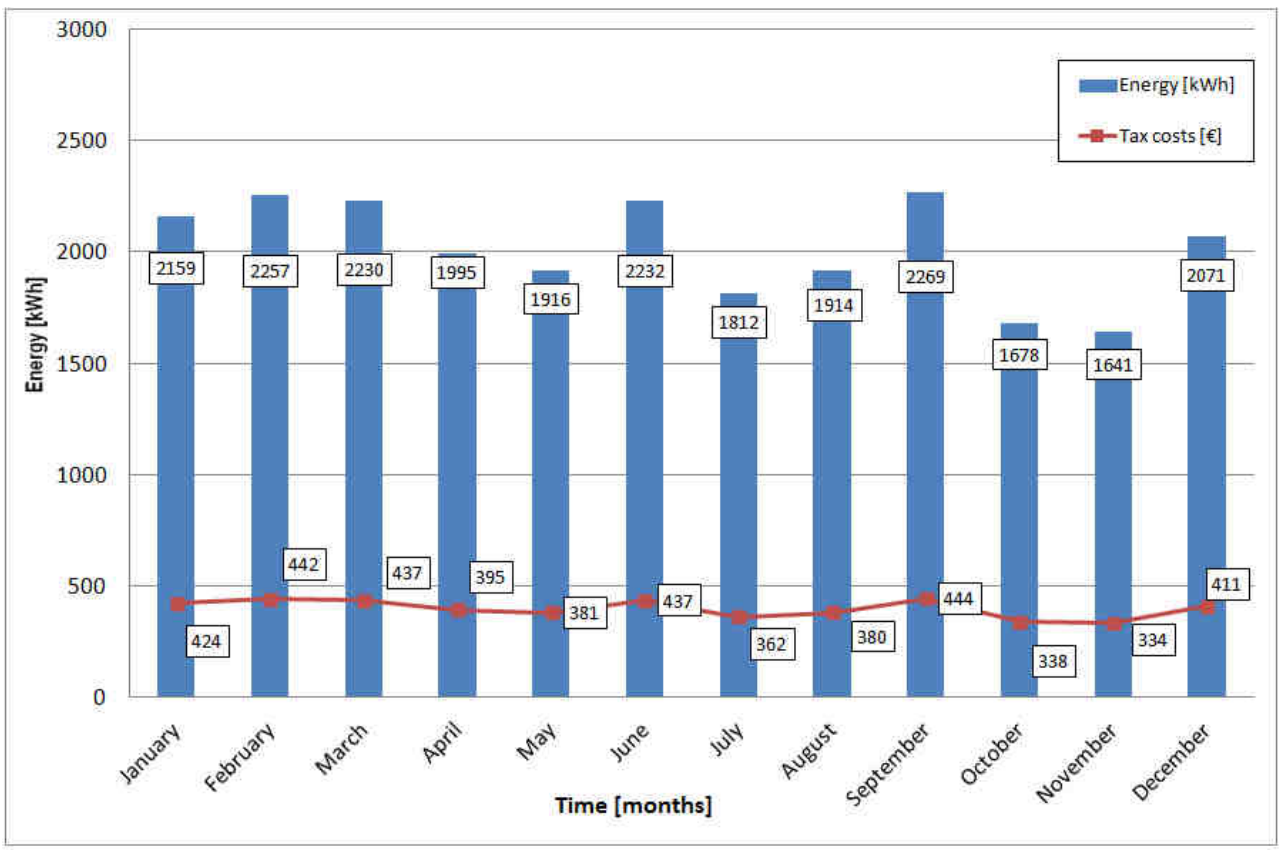

Fig. 11. The registered electricity consumption in particular months, including the costs for the consumed electric energy given in Euro in 2015

Expenditures for the $15.5 \mathrm{kWp}$ power photovoltaic installation

Table 1

\begin{tabular}{|c|c|c|}
\hline \multirow{2}{*}{ Specification } & \multicolumn{2}{|c|}{ Total cost without subsidies } \\
\hline & [PLN] & {$[€]^{*}$} \\
\hline The support structure for 62 photovoltaic panels & 19,000 & 4766 \\
\hline $\begin{array}{l}\text { Installation of } 62 \text { photovoltaic modules with } 250 \mathrm{~W} \text { of a single panel, the } \\
\text { total power of } 15.5 \mathrm{kWp} \text { with the control system and supervising }\end{array}$ & 52,250 & 13,106 \\
\hline Installation of fittings and accessories (inverters, cabling) & 23,750 & 5,957 \\
\hline Total net & 95,000 & 23,829 \\
\hline The total cost gross & $\mathbf{1 1 6 , 8 5 0}$ & 29,309 \\
\hline
\end{tabular}

$* 1 €=3.9868$ PLN $(26.04 .2015)$

\section{Analysis of electricity production from photovoltaic panels}

Production of electricity by photovoltaic panels is closely related to the potential use of solar energy, which significantly depends on the climatic conditions in Poland, and thus cost-effective service life of PV installations.

Average monthly radiation on a horizontal plane in Bialystok occurring in individual months, is shown in Figure 12. In the graph can be observed that the most favorable period is from April to September, it falls on him approximately $79.4 \%$ of the total annual insolation for Bialystok. Whereas the average annual sunshine directly related to the insolation which was $1,720 \mathrm{~h}$ is about $3,230 \mathrm{MJ} / \mathrm{m}^{2}$.

The share of direct radiation in Bialystok total balance of radiation on a horizontal plane per year on average is about $30.7 \%$, which is much smaller than the diffused radiation 
amounting to $69.3 \%$. In the period from January to March and from October to December (winter months) percentage of diffuse radiation is $77.5 \%$, which reflects Figure 12.

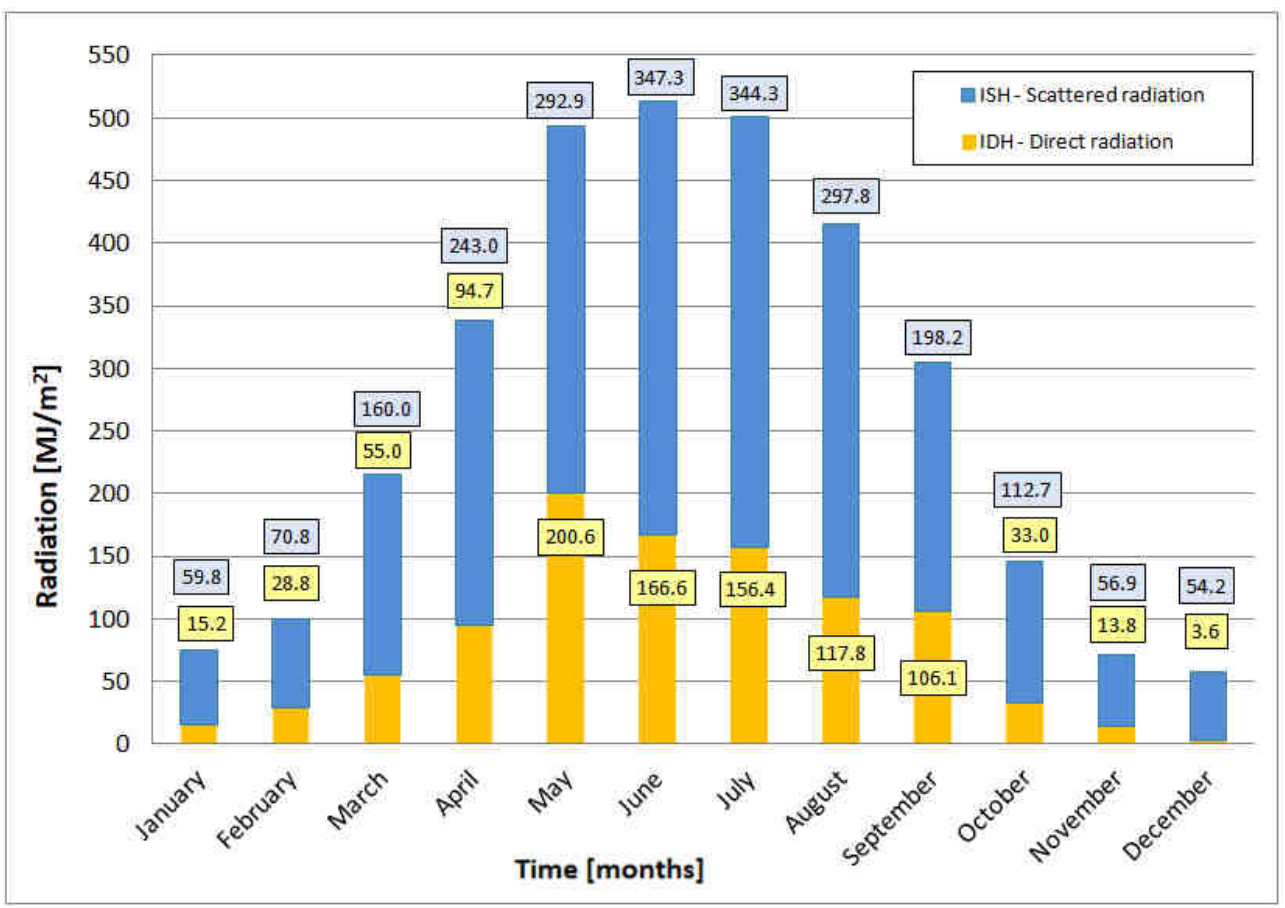

Fig. 12. Monthly radiation between 1971 and 2000 on to the horizontal plane in Bialystok (based on [17])

In Table 2 the intensity of solar radiation $\left[\mathrm{kWh} / \mathrm{m}^{2}\right]$ for installed 62 photovoltaic modules with nominal power of $250 \mathrm{~W}$ each and efficiency of $15.3 \%$ with different angles of inclination of the planes exposed in a southerly direction to the horizon is given. It was estimated for that setting and a total area of photovoltaic panels $\left(F=101.35 \mathrm{~m}^{2}\right)$ annual energy production $[\mathrm{kWh}]$ without taking into account losses caused by shading panels. The system losses because of local shading on the roof of the building through the ventilation ducts, walls of fire and the existing two vacuum solar collectors were $12.5 \%$ and taken into account in Table 3.

For building located in Bialystok the most intense solar radiation for photovoltaic panels directed in a southerly direction can be obtained at summer (June to August) when the PV panels are set at an angle $30^{\circ}$, and the smallest at an angle $90^{\circ}$. The intensity of solar radiation planes exposed in a southerly direction at an angle $30^{\circ}$ amounts in summer $409.6 \mathrm{kWh} / \mathrm{m}^{2}$, and the amount of energy gained from the surface $101.35 \mathrm{~m}^{2}$ of photovoltaic cells is $6,352 \mathrm{kWh}$. By setting the photovoltaic panels at an angle $90^{\circ}$ in the summer time lower solar radiation, by about $18 \%$, can be achieved and therefore a smaller amount of electricity is produced. However, in the winter (December, January, February) the greatest amount of solar radiation intensity is obtained when the angle of photovoltaic panels is $60^{\circ}$ south, it amounts to $90.4 \mathrm{kWh} / \mathrm{m}^{2}$, and the amount of produced electricity is then $1402 \mathrm{kWh}$. By setting the photovoltaic installation during the winter at an angle from 
$0^{\circ}$ to $15^{\circ}$ the lowest yields of solar radiation and the production of electricity from PV panels are obtained.

Table 2

The value of solar radiation $\left[\mathrm{kWh} / \mathrm{m}^{2}\right]$ with different angles settings in a southerly direction and amount of acquired electricity $[\mathrm{kWh}]$ from the surface of photovoltaic panels $F=101.35 \mathrm{~m}^{2}$ without taking into account losses due to local shading in particular months in Bialystok

\begin{tabular}{|c|c|c|c|c|c|c|c|}
\hline \multirow{2}{*}{ Month } & \multicolumn{7}{|c|}{ The intensity of solar radiation $\left[\mathbf{k W h} / \mathbf{m}^{2}\right][17]$} \\
\hline & $\mathbf{0}^{\mathbf{0}}$ & $\mathbf{1 5}^{\mathbf{0}}$ & $25^{\circ}$ & $30^{\circ}$ & $45^{\circ}$ & $\mathbf{6 0}^{\circ}$ & $90^{\circ}$ \\
\hline $\mathbf{I}$ & 20.8 & 24.2 & 26.5 & 27.7 & 30.0 & 31.5 & 31.4 \\
\hline II & 27.7 & 31.9 & 34.7 & 36.1 & 38.8 & 40.2 & 38.7 \\
\hline III & 59.7 & 64.2 & 67.2 & 68.7 & 70.8 & 71.1 & 66.4 \\
\hline IV & 93.8 & 97.3 & 99.6 & 100.7 & 100.9 & 98.8 & 88.4 \\
\hline $\mathbf{V}$ & 137.1 & 139.9 & 141.8 & 142.7 & 139.3 & 131.9 & 108.8 \\
\hline VI & 142.8 & 143.6 & 144.2 & 144.5 & 140.6 & 133.9 & 114.7 \\
\hline VII & 139.1 & 140.5 & 141.4 & 141.9 & 138.6 & 132.4 & 114.2 \\
\hline VIII & 115.5 & 119.4 & 122.0 & 123.3 & 123.1 & 120.2 & 107.2 \\
\hline IX & 84.5 & 90.6 & 94.6 & 96.6 & 98.6 & 97.6 & 87.1 \\
\hline $\mathbf{X}$ & 40.5 & 44.2 & 46.7 & 48.0 & 50.1 & 51.0 & 48.8 \\
\hline XI & 19.7 & 21.9 & 23.4 & 24.2 & 25.7 & 26.5 & 25.9 \\
\hline XII & 16.0 & 16.9 & 17.5 & 17.8 & 18.4 & 18.8 & 18.8 \\
\hline I-XII & 897.1 & 934.6 & 959.6 & 972.1 & 974.8 & 953.7 & 850.4 \\
\hline $\begin{array}{l}\text { Summer } \\
\text { (VI-VIII) }\end{array}$ & 397.3 & 403.5 & 407.6 & 409.6 & 402.3 & 386.5 & 336.1 \\
\hline $\begin{array}{l}\text { Winter } \\
\text { (XII-II) }\end{array}$ & 64.5 & 73.0 & 78.7 & 81.5 & 87.2 & 90.4 & 88.8 \\
\hline
\end{tabular}

\begin{tabular}{|c|c|c|c|c|c|c|c|}
\hline \multirow{2}{*}{ Month } & \multicolumn{7}{|c|}{ The amount of energy acquired [kWh] } \\
\cline { 2 - 8 } & $\mathbf{0}^{\mathbf{0}}$ & $\mathbf{1 5}^{\mathbf{0}}$ & $\mathbf{2 5}^{\mathbf{0}}$ & $\mathbf{3 0}^{\mathbf{0}}$ & $\mathbf{4 5}^{\mathbf{0}}$ & $\mathbf{6 0}^{\mathbf{0}}$ & $\mathbf{9 0}^{\mathbf{0}}$ \\
\hline I & 323.0 & 328.9 & 411.1 & 428.8 & 465.8 & 488.7 & 486.8 \\
\hline II & 429.1 & 432.8 & 538.2 & 560.0 & 601.4 & 622.5 & 599.9 \\
\hline III & 926.4 & 871.2 & $1,041.8$ & $1,064.9$ & $1,097.7$ & $1,102.7$ & $1,029.9$ \\
\hline IV & $1,454.8$ & $1,319.9$ & $1,544.3$ & $1,562.1$ & $1,564.4$ & $1,531.4$ & $1,371.3$ \\
\hline V & $2,125.9$ & $1,898.4$ & $2,198.7$ & $2,213.2$ & $2,160.0$ & $2,045.7$ & $1,686.6$ \\
\hline VI & $2,213.6$ & $1,948.8$ & $2,236.2$ & $2,240.7$ & $2,179.8$ & $2,076.0$ & $1,778.0$ \\
\hline VII & $2,157.0$ & $1,906.2$ & $2,192.8$ & $2,199.9$ & $2,148.8$ & $2,053.0$ & $1,771.4$ \\
\hline VIII & $1,790.4$ & $1,619.6$ & $1,891.3$ & $1,911.5$ & $1,909.2$ & $1,864.1$ & $1,662.9$ \\
\hline IX & $1,310.6$ & $1,228.8$ & $1,466.8$ & $1,498.1$ & $1,528.5$ & $1,512.9$ & $1,351.1$ \\
\hline X & 627.2 & 599.7 & 724.2 & 743.6 & 777.1 & 790.8 & 756.1 \\
\hline XI & 304.8 & 297.4 & 363.3 & 375.0 & 398.0 & 410.5 & 401.7 \\
\hline XII & 248.7 & 229.3 & 270.9 & 275.4 & 284.8 & 290.8 & 290.7 \\
\hline I-XII & $\mathbf{1 3 , 9 1 1 . 5}$ & $\mathbf{1 2 , 6 8 1 . 0}$ & $\mathbf{1 4 , 8 7 9 . 6}$ & $\mathbf{1 5 , 0 7 3 . 2}$ & $\mathbf{1 5 , 1 1 5 . 5}$ & $\mathbf{1 4 , 7 8 9 . 1}$ & $\mathbf{1 3 , 1 8 6 . 4}$ \\
\hline $\begin{array}{c}\text { Summer } \\
\text { (VI-VIII) }\end{array}$ & $6,161.0$ & $5,474.6$ & $6,320.3$ & $\mathbf{6 , 3 5 2 . 1}$ & $6,237.8$ & $5,993.1$ & $5,212.3$ \\
\hline $\begin{array}{c}\text { Winter } \\
\text { (XII-II) }\end{array}$ & $1,000.8$ & 991.0 & $1,220.2$ & $1,264.2$ & $1,352.0$ & $\mathbf{1 , 4 0 2 . 0}$ & $1,377.4$ \\
\hline
\end{tabular}

Table 3

Relative annual energy yield [kWh/kWp] taking into account losses due to local shading for photovoltaic cells $15.5 \mathrm{kWp}$ power depending on the setting angle

\begin{tabular}{|c|c|c|c|c|c|c|c|}
\hline The setting angle of the photovoltaic panels $\left[^{\circ}\right]$ & 0 & 15 & 25 & 30 & 45 & 60 & 90 \\
\hline Annual production $[\mathrm{kWh}]$ taking into account losses & 12,173 & 12,681 & 13,020 & 13,189 & 13,226 & 12,941 & 11,538 \\
\hline The relative annual yield $[\mathrm{kWh} / \mathrm{kWp}]$ & 785 & 818 & 840 & 851 & 853 & 835 & 744 \\
\hline
\end{tabular}


The optimum angle in this case, taking into account the criterion of maximum yield of solar radiation and the amount of electricity produced by the stationary solar photovoltaic systems directed south is an $45^{\circ}$ angle of inclination.

Annual relative yield $[\mathrm{kWh} / \mathrm{kWp}]$ of electricity procured from modules with $1 \mathrm{kWp}$ power, depending on the angle of PV panels inclination has also been calculated. The relative yield of electricity from the $1 \mathrm{kWp}$ power modules, taking into account losses due to the local shading, is shown in Table 3.

Table 4

Predicted relative energy yield $[\mathrm{kWh} / \mathrm{kWp}]$ in particular months at the photovoltaic panels different angles settings towards the south in Bialystok, taking into account losses due to local shading

\begin{tabular}{|c|c|c|c|c|c|c|}
\hline \multirow{2}{*}{ Angle $\left[{ }^{\circ}\right]$} & \multicolumn{5}{|c|}{ Relative energy yield [kWh / kWp] of photovoltaic panels 15.5 kWp power } \\
\cline { 2 - 7 } & January & February & March & April & May & June \\
\hline $\mathbf{0}$ & 18.2 & 24.2 & 52.3 & 82.1 & 120.0 & 125.0 \\
\hline $\mathbf{1 5}$ & 21.2 & 27.9 & 56.2 & 85.2 & 122.5 & 125.7 \\
\hline $\mathbf{2 5}$ & 23.2 & 30.4 & 58.8 & 87.2 & 124.1 & 126.2 \\
\hline $\mathbf{3 0}$ & 24.2 & 31.6 & 60.1 & 88.2 & 124.9 & 126.5 \\
\hline $\mathbf{4 5}$ & 26.3 & 33.9 & 62 & 88.3 & 121.9 & 123.1 \\
\hline $\mathbf{6 0}$ & 27.6 & 35.1 & 62.3 & 86.5 & 115.5 & 117.2 \\
\hline $\mathbf{9 0}$ & 27.5 & 33.9 & 58.1 & 77.4 & 95.2 & 100.4 \\
\hline $\begin{array}{c}\text { The share of energy } \\
\text { production [\%] for the } \\
\mathbf{1 5}^{\circ} \text { angle }\end{array}$ & $\mathbf{2 . 6}$ & $\mathbf{3 . 4}$ & $\mathbf{6 . 9}$ & $\mathbf{1 0 . 3}$ & $\mathbf{1 5 . 0}$ & $\mathbf{1 5 . 4}$ \\
\hline
\end{tabular}

\begin{tabular}{|c|c|c|c|c|c|c|c|}
\hline \multirow{2}{*}{ Angle [ $\left.{ }^{\mathbf{0}}\right]$} & \multicolumn{6}{|c|}{ Relative energy yield [kWh / kWp] of photovoltaic panels 15.5 kWp power } \\
\cline { 2 - 8 } & July & August & September & October & November & December & Total \\
\hline $\mathbf{0}$ & 121.8 & 101.1 & 74.0 & 35.4 & 17.2 & 14.0 & $\mathbf{7 8 5 . 3}$ \\
\hline $\mathbf{1 5}$ & 123.0 & 104.5 & 79.3 & 38.6 & 19.2 & 14.8 & $\mathbf{8 1 8 . 1}$ \\
\hline $\mathbf{2 5}$ & 123.8 & 106.8 & 82.8 & 40.9 & 20.5 & 15.3 & $\mathbf{8 4 0 . 0}$ \\
\hline $\mathbf{3 0}$ & 124.2 & 107.9 & 84.6 & 42 & 21.2 & 15.5 & $\mathbf{8 5 0 . 9}$ \\
\hline $\mathbf{4 5}$ & 121.3 & 107.8 & 86.3 & 43.8 & 22.5 & 16.1 & $\mathbf{8 5 3 . 3}$ \\
\hline $\mathbf{6 0}$ & 115.9 & 105.2 & 85.4 & 44.6 & 23.2 & 16.4 & $\mathbf{8 3 4 . 9}$ \\
\hline $\mathbf{9 0}$ & 100.0 & 93.9 & 76.3 & 42.7 & 22.6 & 16.4 & $\mathbf{7 4 4 . 4}$ \\
\hline $\begin{array}{c}\text { The share of energy } \\
\text { production [\%] for the } \\
\mathbf{1 5}^{\circ} \text { angle }\end{array}$ & $\mathbf{1 5 . 0}$ & $\mathbf{1 2 . 8}$ & $\mathbf{9 . 7}$ & $\mathbf{4 . 7}$ & $\mathbf{2 . 4}$ & $\mathbf{1 . 8}$ & $\mathbf{1 0 0 . 0}$ \\
\hline
\end{tabular}

Based on simulations for the installed $101.35 \mathrm{~m}^{2}$ of photovoltaic panels and power output of $15.5 \mathrm{kWp}$ highest relative annual energy yield, taking into account local losses can be achieved by setting angle of $45^{\circ}$, and the smallest at an angle $90^{\circ}$. Angle of $15^{\circ}$, which was adopted for public building allows for the relative annual energy yield of approximately $818 \mathrm{kWh} / \mathrm{kWp}$. For comparison, the annual energy yield of installed PV system for southern Poland is not less than $942 \mathrm{kWh} / \mathrm{kWp}$ [18-20].

The relative annual electricity yields in individual months of photovoltaic panels with different settings is shown in Table 4, it was also calculated the percentage share of energy produced at an angle $15^{\circ}$ in the next months. The largest electricity production is in June and it amounts to $15.4 \%$ of year-round energy production. In the remaining summer months, the percentages range from 12.8 to $15.0 \%$ [21, 22].

Figure 13 shows the each month relative electricity yield at selected angles of the photovoltaic installations exposed to the south. The numerical values given in the chart in individual months correspond to the set of photovoltaic panels at an angle $15^{\circ}$. 


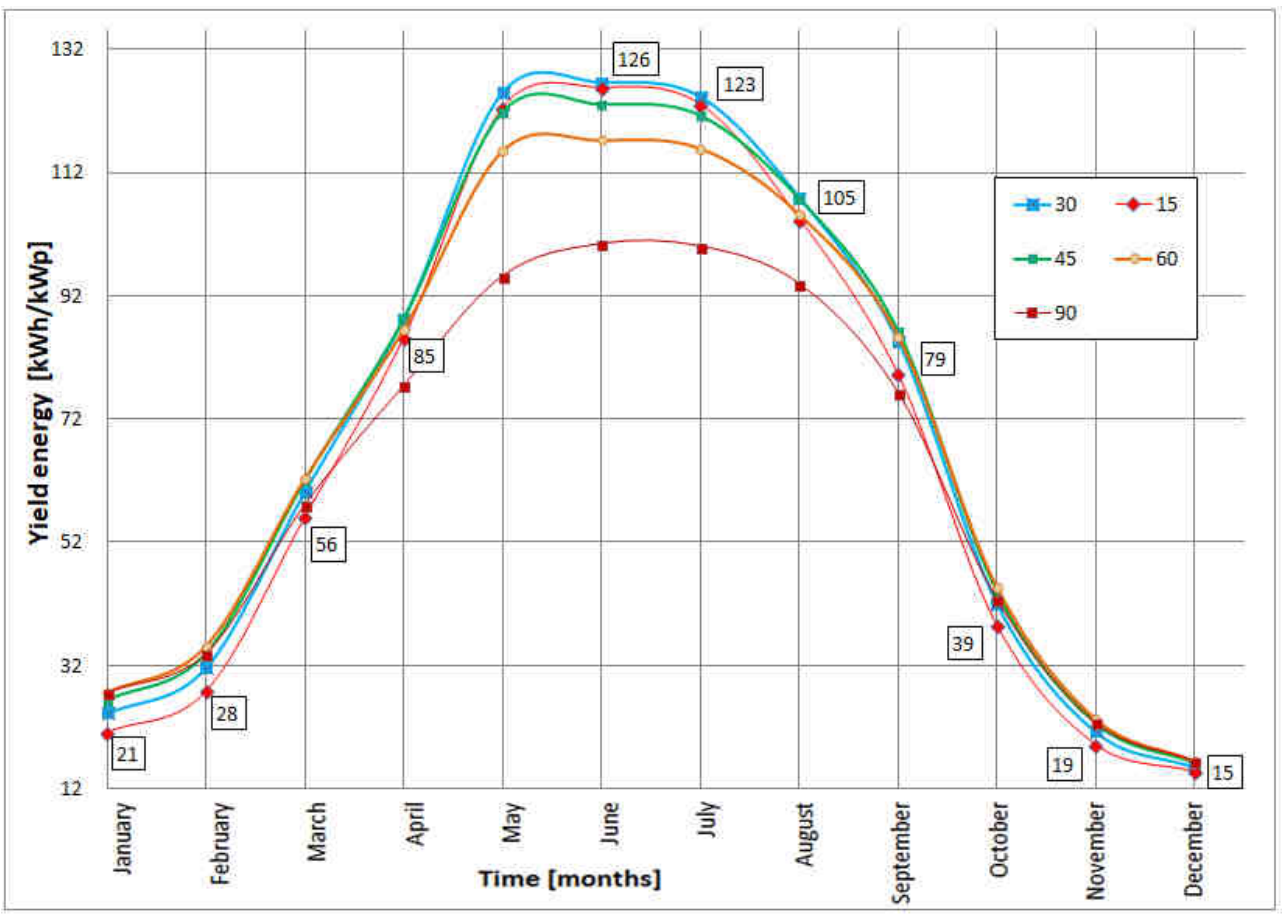

Fig. 13. The relative energy yield from the photovoltaic installation $15.5 \mathrm{kWp}$ power for selected angles $15^{\circ}, 30^{\circ}, 45^{\circ}, 60^{\circ}$ and $90^{\circ}$

If we want to use solar energy to obtain electricity or thermal energy, it is very important to find the optimal angle of the panels [23]. Maximum total radiation energy is the most frequently selected as a criterion for selecting the optimum angle. According to this criterion, the optimum angle of the planes exposed in a southerly direction to the horizontal, for latitude $52^{\circ}$ north, corresponding to Poland, Germany, the Netherlands, and the UK is shown in Table 5. In the case of stationary systems directed south most preferred angle of inclination for the summer period (from May to September) is the angle approximately $42.5^{\circ}$ and for a cold period (from October to April) the angle is about $70^{\circ}$ to the horizontal given by Klugmann-Radziemska [24], while according to Chochowski and Czekalski [25] most optimal angle for the full-year period (from January to December) is the angle $30^{\circ}$, and for a cold period (from April to October) is the angle $23^{\circ}$, the highest values of solar radiation in the summer can be obtained at angles from $10^{\circ}$ to $30^{\circ}$.

Table 5

Optimal flat surface absorbing solar radiation inclination from the horizontal for the latitude $52^{\circ}$ north for the southern exposure [25]

\begin{tabular}{|c|c|c|c|c|c|c|c|c|c|c|c|c|c|c|}
\hline Month & I & II & III & IV & V & VI & VII & VIII & IX & X & XI & XII & IV-X & I-XII \\
\hline $\begin{array}{c}\text { Angle } \\
\text { of inclination [ }{ }^{\circ} \text { ] }\end{array}$ & 60 & 55 & 45 & 30 & 15 & 10 & 15 & 30 & 45 & 55 & 65 & 65 & 23 & 30 \\
\hline
\end{tabular}


The author, after a study of changing the PV panels angle setting, found that the optimum perpendicular installation angle was $45^{\circ}$. When setting panels at an angle of $30^{\circ}$, the relative annual energy yield will be about $0.3 \%$ lower than in the optimum setting.

Taking into account the results obtained in Table 3, having regard the specificity of the terrain, local shading of nearby objects and other PV modules, when it was graphed and it was approximated by the 4th order polynomial fit and by the Gaussian function as shown in Figure 14, the optimum angles were respectively $41^{\circ}$ and $39.5^{\circ}$. The results obtained by the author are very close to the values of the annual optimum slope planes exposed to the south in Poland of about $37^{\circ}$.

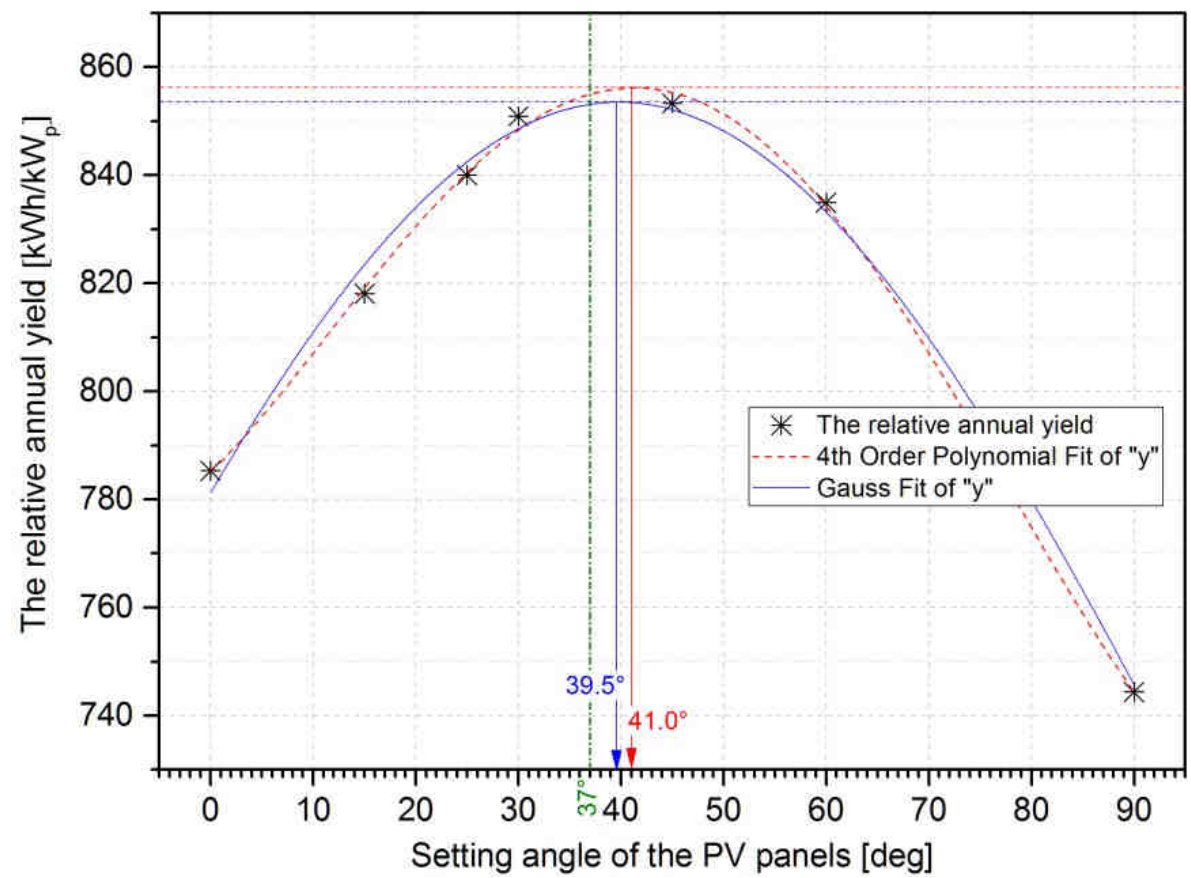

Fig. 14. The optimum angle of the solar panels installation at a relative annual output from PV installation $(15.5 \mathrm{kWp})$

Photovoltaic panels on the roof of the building have been set at an angle of $15^{\circ}$ and directed to the south. The selected angle of PV panels is the most optimal for the summer months, when the highest energy production from the cells occurs, but also the choice of the angle was dependent on technical considerations.

Based on the results can be seen that in the autumn - winter season photovoltaic system reaches a minimum performance due to the limited number of sunny days, as illustrated in Figures 12 and 13. The situation is changing in the spring-summer season, when the plentiful insolation makes the PV system work in the most optimal phase. In the spring-summer season system shows the largest increase in yield electricity (Fig. 13).

In addition to the intensity of solar radiation, the efficiency of photovoltaic cells is strongly influenced by the materials and technology used to produce them. The efficiency of photovoltaic cells from monocrystalline silicon is currently between 18-26.3\% [26-30] 
and from polycrystalline cells is between $14-21.7 \%$ [31, 32]. The lowest efficiency is photovoltaic organic cells $8.7-12.1 \%$, called third generation ones [33, 34]. Continuous technological development increased the efficiency of silicon solar cells to $26.7 \%$, which was confirmed by the Japanese National Institute of Advanced Industrial Science and Technology (AIST) and by the Fraunhofer Institute for Solar Energy Systems (FhG-ISE) in March 2017 [34].

\section{The economic efficiency analysis of the investment-determination of the simple payback time (SPBT) and the investment net present value $(N P V)$}

The project simple payback time (SPBT [years]) related to the installation of $15.5 \mathrm{kWp}$ power photovoltaic system was determined by the formula:

$$
S P B T=\frac{N}{\Delta O_{r}}
$$

where: $N$ - the planned costs of the photovoltaic installation construction [PLN/year]; $\Delta O_{r}$ - annual savings of electricity purchase costs resulting from the application of photovoltaic installation in the building [PLN/year].

Simple payback time defines the time period after which the total savings resulting from the reduction in electricity consumption are equal with the invested capital and will generate the profit to the investor in the form of lower fees for the consumed electric energy, assuming constant energy prices and omit the effect of inflation.

The second indicator of economic efficiency of investments the present value $N P V$ [PLN/year] has been appointed, defined as the sum value of future cash flows from the investment, taking into account the loss of time value of money:

$$
N P V=\sum_{t=1}^{n} \frac{C F_{t}}{(1+r)^{t}}-N
$$

where: $N P V$ - net present value [PLN/year]; $C F_{t}$ - net cash flow in period $\mathrm{t} ; r$ - the discount rate [\%]; $N$ - the planned costs of the photovoltaic installation construction [PLN/year]; $t$ - subsequent years of the investment operation [years].

The annual amount of energy used by office equipment (computers, printers, fax machines, shredders, etc.), electric water heaters, consumed by air-conditioners in the summer, whether consumed on the operation of the devices included in the server room and boiler room (circulation pumps, automation), as well as for lighting during the annual operation of the building is $24,174 \mathrm{kWh} /$ year.

The aim of modernization is to reduce the amount of consumed electricity from conventional sources for technological purposes of the building. The use of PV installations will allow for the reduction and thereby reducing costs for the consumed electricity.

Figure 15 shows the monthly statements of electricity consumption in the building from the PGE network, and forecasted electricity production of photovoltaic PV $15.5 \mathrm{~kW}$ power installations installed in a southerly direction at an angle of $15^{\circ}$ on the roof of the building.

Designing a photovoltaic system produces energy only for their own building. In a situation where the building's energy demand exceeds the production of electricity 
from photovoltaic installations, which takes place in the autumn-winter period (Fig. 15) additional energy is drawn from the PGE power grid.

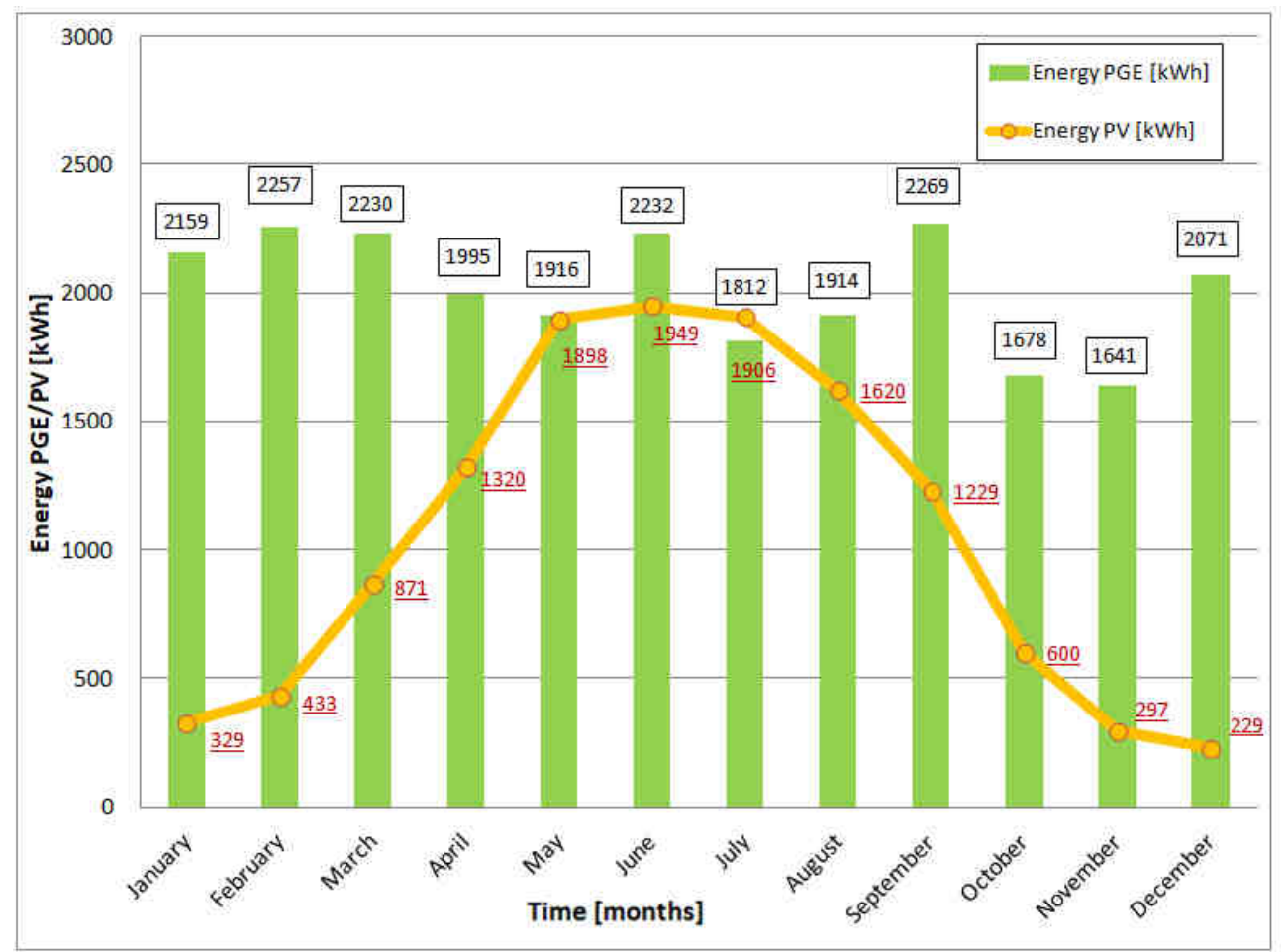

Fig. 15. Consumption of electricity by building from network (PGE) and the amount of electricity produced by photovoltaic (PV) $15.5 \mathrm{kWp}$ power, angled $15^{\circ}$ to the South

Estimated annual output of PV installations $15.5 \mathrm{kWp}$ power will be about $12,681 \mathrm{kWh} /$ year, and the annual relative yield will be about $818 \mathrm{kWh} / \mathrm{kWp}$ (Tables 3 and 4), it decreases the amount of energy drawn from the PGE grid.

The investor in the settlement of electricity uses C11 tariff. The cost for the consumed electricity before installing the photovoltaic system in the building was 19,082 PLN $(4,786.3 €)$.

Table 6 shows the estimated amount of electricity produced, annual savings from the use of PV installations and calculated SPBT and NPV for a period of 15 years. Values are given for two variants - without a subsidy and with a subsidy of $65 \%$ of investment costs $[35,36]$.

After the modernization and installation of photovoltaic system amount of power drawn from the PGE grid will be around 11,493 kWh/year. Fees for electricity in the building after modernization, with charges according to the $\mathrm{C} 11$ tariff will amount to 10,109 PLN/year. Savings from installation of photovoltaic scheduled annually will be about 8,973 PLN/year (2,251 €/year). 
Forecasting the amount of electricity produced from PV installations, annual cost savings, simple payback time $S P B T$ and investment net present value $(N P V)$

\begin{tabular}{|c|c|c|c|c|c|}
\hline Venture & $\begin{array}{c}\text { The amount of electric } \\
\text { energy PV } \\
\text { [kWh/year] }\end{array}$ & $\begin{array}{c}\text { Savings } \Delta O_{r} \\
\text { [PLN/year] }\end{array}$ & $\begin{array}{c}\text { Capital } \\
\text { expenditure } \\
N \text { [PLN] }\end{array}$ & $\begin{array}{c}S P B T \\
\text { [years] }\end{array}$ & $\begin{array}{l}N P V \\
{[\text { PLN] }}\end{array}$ \\
\hline \multirow{4}{*}{$\begin{array}{l}\text { Installation of } \\
\text { photovoltaic } \\
\text { system } \\
15.5 \mathrm{kWp}\end{array}$} & \multirow{4}{*}{12,681} & \multirow{4}{*}{8,973} & \multicolumn{3}{|c|}{ without subsidies } \\
\hline & & & 116,850 & 13.0 & $-19,816$ \\
\hline & & & \multicolumn{3}{|c|}{ with subsidies $65 \%$} \\
\hline & & & 40,898 & 4.6 & 56,136 \\
\hline
\end{tabular}

Simple payback time, in the absence of funding, will be approximately 13 years. When installing the photovoltaic $15.5 \mathrm{kWp}$ power system investor benefited from the funding, hence the expected payback period will be 4.6 year. In the absence of subsidizing investments $N P V$ is negative, this means that in real terms the expenditure on investment will not return to the investor, and therefore realization of investments in this case is unprofitable from the point of view of the investor. Only in the case of grants for investments you can count on the success of the project. A positive NPV means that the project offers capital growth faster than the discounting rate, and therefore is an profitable investment [37, 38].

Keep in mind that the $N P V$ calculate is based on forecast cash flows from new business in the period of several years. The key size, which affects the value of this indicator, in addition to the actual results of the new business has a value used to calculate the discount rate, which in practice is similar to the interest rates on bonds or bank deposits.

Using funding under the Regional Operational Programme Podlaski, Activity 5.2. The development of local infrastructure for environmental protection, for a period of five years, the investor cannot sell surplus energy produced from PV installations. After this period, when the electricity produced from PV installations will exceed the demand of the building, the surplus of electricity, mainly in the summer months, during the holiday period, can be sell to the grid, which will bring additional benefits to the investor.

The photovoltaic system (Figs. 9 and 10) has been launched for the first time in late December 2014 and produced $77 \mathrm{kWh}$ of electricity PV. Production of electricity from PV installations in the winter as expected and simulations, was not high. In 2015 registered production of electricity from PV installations was amounted to $11,286 \mathrm{kWh}$. That is the real amount of energy actually produced from PV and energy consumed by a building during this period. It is about $11 \%$ lower than it would with forecasts, taking into account local losses.

\section{Emissions of carbon dioxide and other harmful substances reduction after the photovoltaic panels application}

Actual registered electricity consumption for the needs of about $24,174 \mathrm{kWh}$ shows Figure 11. Summary of the amount of electricity produced by photovoltaic PV $15.5 \mathrm{kWp}$ power angled 15 degrees to the south, taking into account the local losses is prognostic ally $12,681 \mathrm{kWh} /$ year and is presented for each month on Figure 13. Based on these data, reduce emissions of carbon dioxide and other harmful substances after application of photovoltaic panels is calculated in this article. 
In Poland, emissions to the atmosphere when using the electric energy network is connected with the production technology based on coal.

The size of the annual emissions $\left(\mathrm{CO}_{2}, \mathrm{SO}_{2}, \mathrm{NO}_{\mathrm{x}}\right.$ and dust $)$ in a building are calculated with the emissions indicators $[39,40]$.

Ecological effects, $\Delta E$, resulting from the reduction of the amount of pollutants that can be obtained as a result of the installed photovoltaic system was determined as the difference of emissions of pollutants into the air with electricity consumption excluding photovoltaic installation work and the electricity consumption including the work of the photovoltaic system. It was determined from the relationship:

$$
\Delta E=E_{0}-E_{1}
$$

where: $E_{0}$ - the annual emissions of pollutants $\left(\mathrm{SO}_{2}, \mathrm{NO}_{\mathrm{x}}, \mathrm{CO}_{2}\right)$ resulting from the consumption of electricity in the building without taking into account the electricity produced by the photovoltaic system [kg/year]; $E_{1}$ - annual emissions of pollutants $\left(\mathrm{SO}_{2}\right.$, $\mathrm{NO}_{\mathrm{x}}, \mathrm{CO}_{2}$ ) resulting from electricity consumption in the facility including the production of electricity from photovoltaic installation [kg/year].

Annual emissions of pollutants $\left(\mathrm{SO}_{2}, \mathrm{NO}_{\mathrm{x}}, \mathrm{CO}_{2}\right)$ introduced into the air resulting in the use of electricity without considering and taking into account operation of the photovoltaic plant are determined from the following relationship:

$$
E_{0}, E_{1}=B_{0}, B_{1} \cdot w
$$

where: $B_{0}, B_{1}$ - annual amount of electricity consumed without consideration of the photovoltaic plant operation and taking into account of the photovoltaic plant operation [MWh/year]; $w$ - emission factor of sulfur dioxide, nitrogen dioxide, carbon dioxide, according to $[\mathrm{kg} / \mathrm{MWh}],[\mathrm{Mg} \mathrm{CO} / \mathrm{MWh}]$.

Dust emissions $E_{\text {dust }}[\mathrm{kg} /$ year] was determined based on the following relationship:

$$
E_{\text {dust } 0}, E_{\text {dust } 1}=B_{0}, B_{1} \cdot w^{\wedge} \cdot(100-\eta) /(100-k)
$$

where: $w^{\wedge}$ - dust drift indicator [kg/fuel Mg]; $\eta$ - dust collector efficiency [\%]; $k$ - content of combustible dust, according to the Certificate of fuel [\%].

To calculate the annual emission reductions from the use of the electricity network, the following emission factors were took into account: sulfur dioxide $w=2.203 \mathrm{~kg} / \mathrm{MWh}$, nitrogen dioxide $w=1.230 \mathrm{~kg} / \mathrm{MWh}$, sling dust $w^{\wedge}=1.812 \mathrm{~kg} / \mathrm{MWh}$, carbon dioxide $w=0.812 \mathrm{Mg} \mathrm{CO}_{2} / \mathrm{MWh}[39-41]$.

Predictive reduction of emissions entering to the atmosphere

\begin{tabular}{|c|c|c|c|c|c|c|}
\hline \multirow[b]{2}{*}{ No. } & \multirow[b]{2}{*}{ Pollutants } & \multirow{2}{*}{$\begin{array}{l}\text { The emission } \\
\text { factor }\end{array}$} & \multicolumn{2}{|c|}{ Emission of pollutants [kg/year] } & \multicolumn{2}{|c|}{$\begin{array}{c}\text { Reduction } \\
\text { of emissions }\end{array}$} \\
\hline & & & $\begin{array}{l}\text { Excluding the } \\
\text { photovoltaic } \\
\text { installation }\end{array}$ & $\begin{array}{l}\text { Taking into account the } \\
\text { photovoltaic installation }\end{array}$ & {$[\mathrm{kg} /$ year $]$} & [\%] \\
\hline \multicolumn{7}{|c|}{ Electricity from the Polish electricity network } \\
\hline 1 & $\mathrm{SO}_{2}$ & $2.203 \mathrm{~kg} / \mathrm{MWh}$ & 53 & 25 & 28 & 52.3 \\
\hline 2 & $\mathrm{CO}_{2}$ & $812 \mathrm{~kg} \mathrm{CO} / \mathrm{MWh}$ & 19,629 & 9,332 & 10,297 & 52.5 \\
\hline 3 & Dust & $1.812 \mathrm{~kg} / \mathrm{MWh}$ & 44 & 21 & 23 & 52.3 \\
\hline 4 & $\mathrm{NO}_{\mathrm{x}}$ & $1.230 \mathrm{~kg} / \mathrm{MWh}$ & 30 & 14 & 16 & 53.3 \\
\hline
\end{tabular}
after the $15.5 \mathrm{kWp}$ photovoltaic installation application 


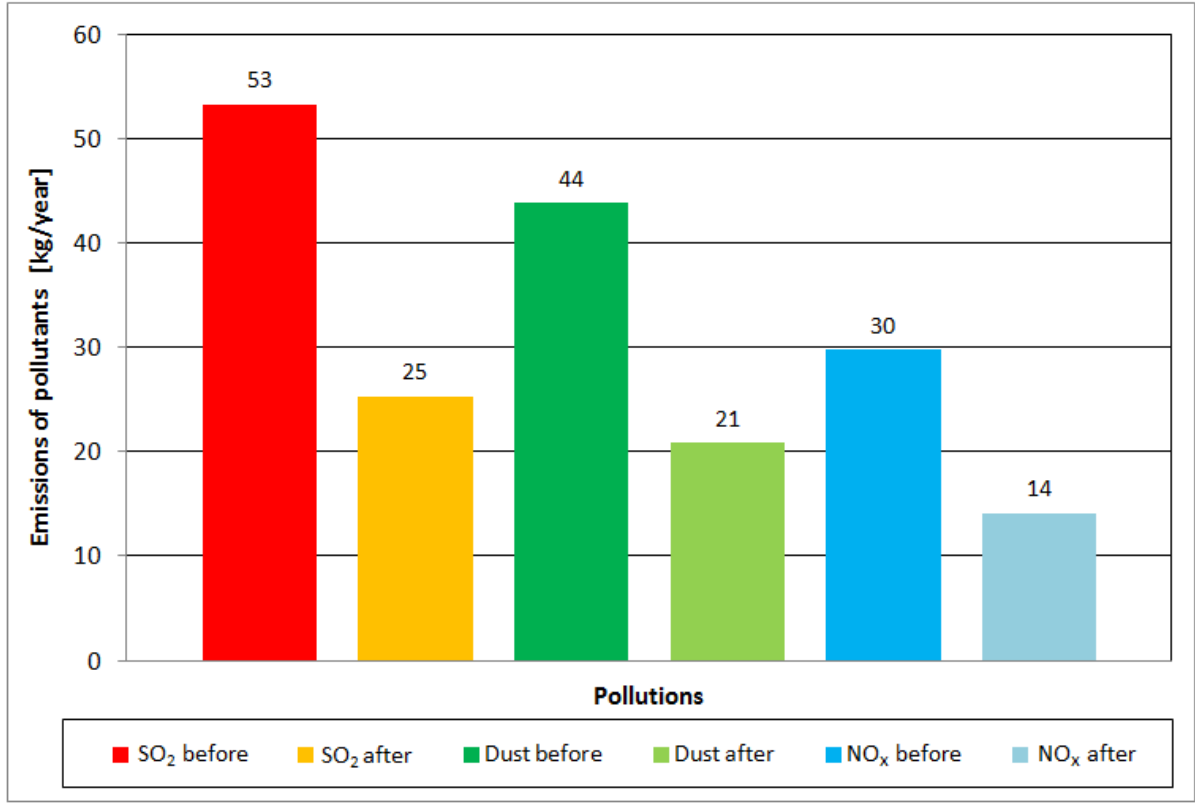

Fig. 16. Calculated emissions of $\mathrm{SO}_{2}, \mathrm{NO}_{\mathrm{x}}$ and dust before and after the photovoltaic system installation $15.5 \mathrm{kWp}$

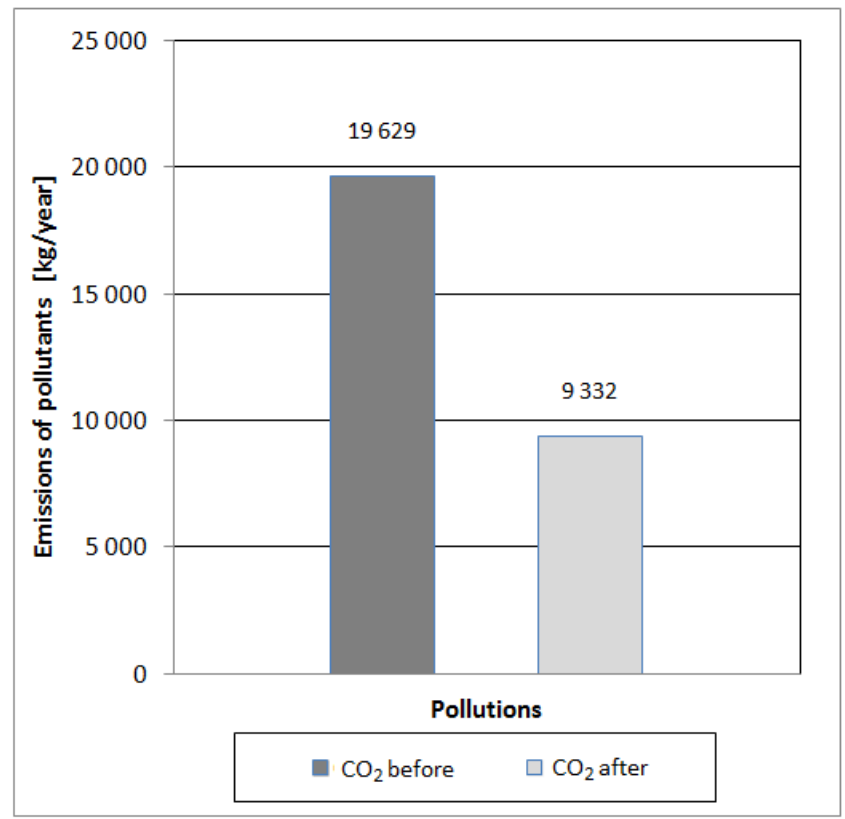

Fig. 17. Calculated $\mathrm{CO}_{2}$ emissions before and after the photovoltaic system installation in the building 
After application of photovoltaic systems with a total nominal power of $15.5 \mathrm{kWp}$ to support electricity production with the participation of solar energy, a reduction of emissions into the atmosphere were achieved, the amount of reduction was about $52 \%$.

Table 7 shows the results of calculations of emissions before and after the installation of a photovoltaic system in the building. Pollution reduction calculations were made based on the values obtained by simulation.

The values of the relative reduction of emissions of $\mathrm{SO}_{2}, \mathrm{NO}_{\mathrm{x}}$, and dust in [\%] in graphical form is shown in Figures 16 and 17 shows graphically the reduction of $\mathrm{CO}_{2}$ emissions.

\section{Conclusions}

The aim of the modernization was to reduce the amount of consumed electric energy from conventional sources for technological purposes of the building. The application of PV installations will allow for the electric energy reduction by $52.5 \%$ and simultaneously will reduce carbon dioxide emissions to the environment by $10,297 \mathrm{~kg} / \mathrm{year}(52.5 \%)$. The investment was financed at 65\% under the ROP Podlaski 2007-2013 and in 35\% of own funds. When the investment is supported payback period is expected in less than five years, the $N P V$ is positive, the investor can count on the success of the project. In the absence of subsidizing investments $N P V$ is negative, in this case the investment is not profitable without subsidies from the point of view of the investor, the payback time is approximately 13 years.

Costs for the consumed electricity after the photovoltaic system installation will decrease by 8,973 PLN (2,251 €/year).

The building photovoltaic system is working only for their own needs. When demand for electricity of the building exceeds the production from the photovoltaic installations, additional energy is taken from the power grid PGE.

The electricity generated from PV panels will cover 52.5\% of the total electric energy demand of the building and approximately so much will decrease emissions to the atmosphere after the installation of the photovoltaic installation.

PV modules performance during the summer is very high, this is related to from intensity of solar radiation, which in Polish is most intense in the spring-summer season.

Installation of the photovoltaic working of technology needs in the object improves the environment by reducing the gaseous emission and dust. It also helps to promote the local market for other forms of energy generation, and not only the use of energy from non-renewable sources. It allows raise public awareness of the need and the possibility of using renewable energy sources, as well as improves energy security of the region and contributes to the attractiveness and competitiveness of Podlaskie.

\section{Acknowledgements}

The study has been implemented from the resources of the S/WBiIŚ/4/14 statutory work financed by the Ministry of Science and Higher Education in Poland.

\section{References}

[1] Burg BR, Selviaridis A, Paredes S, Michel B. Ecological and economical advantages of efficient solar systems, CPV-10. AIP Conference Proc.1616. 2014;1:317-320. DOI: 10.1063/1.4897086. 
[2] Sathe TM, Dhoble AS. A review on recent advancements in photovoltaic thermal techniques. Renew Sust Energy Rev. 2017;76:645-672. DOI: 10.1016/j.rser.2017.03.075.

[3] Lai SC, Jia Y, Lai LL, Xu Z, McCulloch MD, Wong KP. A comprehensive review on large-scale photovoltaic system with applications of electrical energy storage. Renew Sust Energy Rev. 2017;78:439-451. DOI: 10.1016/j.rser.2017.04.078

[4] Branker K, Pathak M, Pearce J. A review of solar photovoltaic levelized cost of electricity. Renew Sustain Energy Rev. 2011;15(9):4470-4482. DOI: 10.1016/j.rser.2011.07.104.

[5] Directive (EU) 2015/1513 of the European Parliament and of the Council of 9 September 2015 amending Directive 98/70/EC relating to the quality of petrol and diesel fuels and amending Directive 2009/28/EC on the promotion of the use of energy from renewable sources. http://eur-lex.europa.eu/eli/dir/2015/1513/oj.

[6] IEC 61724: Photovoltaic System Performance Monitoring - Guidelines for Measurement, Data Exchange and Analysis. https://webstore.iec.ch/preview/info_iec61724\%7Bed1.0\%7Den.pdf.

[7] Rawat R, Lamba R, Kaushik SC. Thermodynamic study of solar photovoltaic energy conversion: An overview. Renew Sustain Energy Rev. 2017;71:630-638. DOI: 10.1016/j.rser.2016.12.089.

[8] Piotrowska-Woroniak J, Załuska W, Woroniak G. Energy production from PV and carbon reduction in great lakes region of Masuria Poland: A case study of water park in Elk. Renev Energy. 2015;83:1315-1325. DOI: 10.1016/j.renene.2015.05.034.

[9] Green MA, Emer K, Hishikawa Y, Warta W, Dunlop ED. Solar cell efficiency tables (ver. 47). Progress Photovolt: Res Appl. 2016;24(1):3-11. DOI: 10.1002/pip.2728.

[10] Bhubaneswari P, Iniyan S, Goic R. A review of solar photovoltaic technologies. Renew Sust Energy Rev. 2011;15(3):1625-1636. DOI: 10.1016/j.rser.2010.11.032.

[11] Caamaño-Martín E, Lorenzo E, Lastres C. Crystalline silicon photovoltaic modules: characterization in the field of rural electrification. Progr Photovolt Res Appl. 2002;10:481-493. DOI: 10.1002/pip.436.

[12] Shanks K, Senthilarasu S, Mallick TK. Optics for concentrating photovoltaics: Trends, limits and opportunities for materials and design. Renew Sustain Energy Rev. 2016;60(3):394-407. DOI: 10.1016/j.rser.2016.01.089.

[13] Gueymard CA. A review of validation methodologies and statistical performance indicators for modeled solar radiation data: Towards a better bankability of solar projects. Renew Sustain Energy Rev. 2014; 39:1024-1034. DOI: 10.1016/j.rser.2014.07.117.

[14] Sobolewski A. Audyt elektroenergetyczny instalacji i urządzeń budynku biurowego w Białymstoku [Audit of electrical power systems and equipment of the office building in Bialystok]. Białystok: Developed by Coral Perkowski W, Perkowski J. general partnership; 2013.

[15] Wacławek M, Rodziewicz T. Ogniwa słoneczne. Wpływ środowiska naturalnego na ich pracę. [Solar cells. The impact of the environment on their work]. II ed. Warszawa: WNT; 2015.

[16] Madeti SR, Singh SN. Monitoring system for photovoltaic plants: A review. Renew Sust Energy Rev. 2017;67:1180-1207. DOI: 10.1016/j.rser.2016.09.088.

[17] http://mib.gov.pl/2-Wskazniki_emisji_wartosci_opalowe_paliwa.htm (Bialystok ISO STAT. TXT) (access 10.04.2015). (Emission factors, calorific values of fuel, typical meteorological years and statistical climatic data for building energy calculations).

[18] Page J, Albuisson M, Wald L. The European solar radiation atlas: a valuable digital tool. Solar En. 2001;71:81-83. DOI: 10.1016/S0038-092X(00)00157-2.

[19] Almeida MP, Perpiñán O, Narvarte L. PV power forecast using a nonparametric PV model. Solar Energy. 2015;115:354-368. DOI: 10.1016/j.solener.2015.03.006.

[20] Ramsami P, Oree V. A hybrid method for forecasting the energy output of photovoltaic systems. Energy Conv Manage. 2015;95:406-413. DOI:10.1016/j.enconman.2015.02.052.

[21] Denholm P, Margolis RM. Evaluating the limits of solar photovoltaics (PV) in traditional electric power systems. Energy Policy. 2007;35(5):2852-2861. DOI:10.1016/j.enpol.2006.10.014.

[22] Lupangu C, Bansal RC. A review of technical issues on the development of solar photovoltaic systems, Renew Sustain Energy Rev. 2017;73:950-965. DOI: 10.1016/j.rser.2017.02.003.

[23] Mehleri ED, Zervas PL, Sarimveis H, Palyvos JA, Markatos NC. Determination of the optimal tilt angle and orientation for solar photovoltaic arrays. Renew Energy. 2010;35(11):2468-2475. DOI: 10.1016/j.renene.2010.03.006.

[24] Klugmann-Radziemska E. Praktyczne wykorzystanie energii słonecznej, Odnawialne Źródła Energii Opolszczyzny [The practical use of solar energy, Renewable Energy Sources Opole]. Opole: Project funded by the European Union under the European Social Fund No.1 / POKL / 8.2.1; 2008. (www.oze.opole.pl/zalacznik.php?id=355\&element=471).

[25] Chochowski A, Czekalski D. Słoneczne instalacje grzewcze [Solar heating systems]. Warszawa: COIB; 1999. 
[26] Lan CW, Lan A, Yang CF, Hsu HP, Yang M, Yu A, et al. The emergence of high-performance multi-crystalline silicon in photovoltaics. J Crystal Growth. 2017;468:17-23. DOI: 10.1016/j.jcrysgro.2016.10.072.

[27] http://www.solar-frontier.com/eng/news/2017/0227_press.html.

[28] Bush KA, Palmstrom AF, Yu ZJ, Boccard M, Cheacharoen R, Mailoa JP, et al. 23.6\%-efficient monolithic perovskite/silicon tandem solar cells with improved stability. Nature Energy. 2017;2(4):17009. DOI: 10.1038/nenergy.2017.9.

[29] Schindler F, Michl B, Krenckel P, Riepe S, Benick J, Müller R, et al. How to achieve efficiencies exceeding $22 \%$ with multicrystalline n-type silicon solar cells. Energy Procedia. 2017;124:777-780. DOI: 10.1016/j.egypro.2017.09.086.

[30] Yoshikawa K, Kawasaki H, Yoshida W, Irie T, Konishi K, Nakano K, et al. Silicon heterojunction solar cell with interdigitated back contacts for a photoconversion efficiency over 26\%. Nature Energy. 2017;2:17032. DOI: $10.1038 /$ nenergy.2017.32.

[31] https://commons.wikimedia.org/wiki/File:Best_Research-Cell_Efficiencies.png

[32] Kato T, Handa A, Yagioka T, Matsuura T, Yamamoto K, Higashi S, et al. Enhanced efficiency of Cd-free $\mathrm{Cu}(\mathrm{In}, \mathrm{Ga})(\mathrm{Se}, \mathrm{S})_{2}$ minimodule via $(\mathrm{Zn}, \mathrm{Mg}) \mathrm{O}$ second buffer layer and alkali metal post-treatment. IEEE J Photov. 2017;7(6):1773-1780. DOI: 10.1109/JPHOTOV.2017.2745710.

[33] Green MA, Emery K, Hishikawa Y, Warta W, Dunlop ED, Levi DH, et al. Solar cell efficiency tables (version 49). Progr Photovolt: Res Appl. 2016;25(1):3-13. DOI: 10.1002/pip.2855.

[34] Green MA, Emery K, Hishikawa Y, Warta W, Dunlop ED, Levi DH, et al. Solar cell efficiency tables (version 50). Progr Photovolt: Res Appl. 2017;25(7):668-676. DOI: 10.1002/pip.2909.

[35] Dong Y, Jingru L, Jianxin Y, Ning D. Life-cycle assessment of China's multi-crystalline silicon photovoltaic modules considering international trade. J Cleaner Product. 2015;94(1):35-45. DOI: 10.1016/j.jclepro.2015.02.003.

[36] Dusonchet L, Telaretti E. Comparative economic analysis of support policies for solar PV in the most representative EU countries. Renew Sust Energy Rev. 2015;42:986-998. DOI: 10.1016/j.rser.2014.10.054.

[37] Lamnatou C, Chemisana D. Evaluation of photovoltaic-green and other roofing systems by means of ReCiPe and multiple life cycle-based environmental indicators. Building Environ. 2015;93(2):376-384. DOI: 10.1016/j.buildenv.2015.06.031.

[38] William R, Goodwell A, Richardson M, Kumar P, Stillwell AS. An environmental cost-benefit analysis of alternative green roofing strategies. Ecol Eng. 2016;95:1-9. DOI: 10.1016/j.ecoleng.2016.06.091.

[39] Wskaźniki opałowe (WO) i wskaźniki emisji $\mathrm{CO}_{2}$ (WE) w roku 2012 do raportowania w ramach Wspólnotowego Systemu Handlu Uprawnieniami do Emisji za rok 2015. Krajowy Ośrodek Bilansowania i Zarządzania Emisjami [Combustion Indicators (WO) and the emission of $\mathrm{CO}_{2}$ (WE) in 2012 for reporting under the Community of the Emissions Trading for the year 2015]. Warszawa: the National Centre for Emissions Balancing and Management; November 2014. (http://www.kobize.pl/uploads/materialy/materialy_do_pobrania/monitorowanie_raportowanie_weryfikacja_ emisji_w_eu_ets/WO_i_WE_do_stosowania_w_SHE_2015.pdf).

[40] Pacca S, Sivaraman D, Keoleian GA. Parameters affecting the life cycle performance of PV technologies and systems. Energy Policy. 2007;35(6):3316-3326. DOI: 10.1016/j.enpol.2006.10.003.

[41] Fthenakis V, Kim HC, Alsema E. Emissions from photovoltaic life cycles. Environ Sci Technol. 2008;42(6):2168-2174. DOI: 10.1021/es071763q. 